DANDELION

postgraduate arts journal \& research network

YOLUME 3 NUMBER I WINTER 2012 I BREVITY

Conference Review
JAMES WILPER is a PhD candidate, funded through the Birkbeck International Research Studentship, researching early twentieth-century gay novels of the German- and Englishlanguage contexts. He has taught in the German section of Birkbeck's Department of European Cultures and Languages, published two articles in the areas of comparative literature, and since autumn 2009 has been Dandelion's sectional editor for European Cultures and Languages.

Email: jameswilper@gmail.com

\title{
MODERNIST EROTICISMS
}

\author{
Institute for Germanic and Romance Studies
}

\author{
20 May 2011
}

\begin{abstract}
James Wilper
I HAVE OBSERVED AMONGST MY FELLOW POSTGRADUATE STUDENTS a growing cynicism towards academic conferences. The view is that conferences are less about sharing knowledge and more about networking whilst showing other scholars how brilliantly clever one is. While the Modernist Eroticisms conference, which was co-organised by the Centre for Modern European Literature at the University of Kent and the Institute for Germanic and Romance Studies, was not free of the latter, it was an excellent argument for the validity of the conference as a forum for the exchange of knowledge.

The one-day conference was held at the IGRS on 20 May 2011 and coordinated by Dr Anna Katharina Schaffner (Kent/IGRS) and Dr Shane Weller (Kent). Whilst small in scale the conference was far-reaching in scope: composed of six, forty-minute papers by leading scholars in Britain in the fields of Modernist European literature and culture; ranging in topic from the erotics of Modernist style to the changing apparatuses of the confession of sex.

In its general aim the conference sought to explore aspects of the interaction in the late nineteenth century between literature and the newly emergent field of sexology. As Schaffner pointed out in her introductory talk, the exchange between literature and science was omnidirectional:
\end{abstract}


It is not by accident that the names of two literary figures, the Marquis de Sade and Leopold von Sacher-Masoch, were appropriated by clinical discourse to categorize sexual pathologies. Richard von Krafft-Ebing, Sigmund Freud and many other sexologists drew extensively on literary sources to illustrate their theoretical models.

In turn, late nineteenth- and early twentieth-century sexological discourse impacted upon Modernist writings, with these authors drawing upon, responding to, and revalorizing medical and psychiatric models of perversions.

Two highlights of the conference were the papers given by Profs Elizabeth Boa (Nottingham) and Ritchie Robertson (Oxford), two of the most preeminent Germanists in British academia. Boa's paper, titled 'Innocent Monsters: the Erotic Child in Early Modernism', explored pre-Freudian depictions of child sexuality in a range of fin-de-siècle and early twentieth century English-, German-, and French-language texts, including: Henry James's novels What Maisie Knew (1897) and Turn of the Screw (1898); and Franz Wedekind's plays Frühlings Erwachen [Spring Awakening] (1889) and Die Büchse der Pandora. Eine Monstretragödie [Pandora's Box] (1894). The common and recurrent theme in these works, according to Boa, is the blurring of lines between childhood love and sexual love, as well as between that of homo- and heterosexual love. The literature problematizes the Victorian cult of childhood innocence and, as in the case of Wedekind's Spring Awakening, even attacks this cult head on. The works point to eras of new freedom, but there is uncertainty as well, a marked angst of whether this freedom will bring the end of society.

In contrast to Boa, who charts common themes across European and English literature, Robertson's paper, titled "Im Anfang war der Leib": Polymorphous Eroticism in the Early Plays of Hans Henny Jahnn', focuses on the output of a single writer, Hans Henny Jahnn (1894-1959), whose works are not well known outside the German-speaking world. These early plays evince, according to Robertson, not merely a fascination with the body-hence the title of his paper 'Im Anfang war der Lieb' [In the beginning, there was the body] but a cult of the body that degenerates into a morbid obsession with death. In the plays Pastor Ephraim Magnus (1919), Die Krönung Richards III. [The Coronation of Richard III] (1921), and Medea (1926), the motifs of masochism, fear of women, sympathy with crimes of passion, and preoccupation with the decay of the body recur. Robertson argues that the violence of Jahnn's war-time and post-war plays-Jahnn himself was a committed pacifist who spent the First World War in exile in a commune in neutral Norway-represents a reflection on the wider violence perpetrated across Europe.

Whilst the long-form papers provided a richness of knowledge and discussion, this particular format also proved to be the least effective aspect of the conference. It was sometimes difficult to follow the complexity and intricacies of an argument over the course of a forty-minute talk. By the time the question session rolled around, I found myself forgetting to ask questions that seemed urgent in the first ten or fifteen minutes. Nevertheless, the conference achieved a synergy of cross-cultural and interdisciplinary research that I have come to discover is rare in British academia.

This synergy and insightful discussion carried over from the papers into casual conversations over lunch and in the coffee and tea breaks. This is 
undoubtedly one of the hardest parts of a conference to plan for, but in this instance both speakers and delegates seemed to enjoy the open conversation so much so that the breaks always ran long. The personal highlight of the conference for me was speaking with Robertson during the first tea break. When such a prominent figure expresses not just polite interest in the work of a young researcher, but thinks that you are actually on to something, it is naturally an elating experience and helps put to rest any doubts that one might be having about the direction of one's thesis.

An additional note to the reader: When writing this review it occurred to me that this conference begged to be reviewed in the style of my favourite Modernist writer, Thomas Mann. Few writers of the era depicted erotic longing with such accomplished literary style. Take, for instance, Gustav von Aschenbach's pursuit of the ephebe Tadzio in Mann's masterpiece of homoerotic Sehnsucht, the 1912 novella Death in Venice. But I decided against that approach, uncertain of where such an exercise might lead. I expect, after rhapsodizing the beauty of one of the conference participants or one of my fellow attendees in such a review, it would end in a sexual harassment charge. This fact highlights the fine line one treads when researching in this field. We talk constantly about sex, but in such abstract ways that it de-sexualizes sex, making it politically correct and fit material for the classroom, academic publications, and conferences such as this one.

Birkbeck College, University of London 